\title{
規 定
}

\section{森林計画学会誌編集委員会規定}

\section{第 1 条（設定）}

森林計画学会会則第 7 条第 3 項に基づき編集委員会 （以下委員会と呼ぶ）規定を以下のように定める。

\section{第2条（任務）}

第 1 項 委員会は和文誌と英文誌の編集および学会 活動記録に関わる以下の事項を処理する。

\section{1. 原稿が投稿規定および執筆要領に準拠してい ることを確認すること。}

2. 查読者（2名以上）を決定し，審査を依頼す ること。査読者の氏名は公表しない。

3．審査の結果を審議し，会誌への掲載の可否を 決定すること。
4. 学会活動の記録や会誌の編集・印刷に関わる 必要事項。

第 2 項 審査の結果，原稿の会誌への掲載が認めら れない場合, 編集委員長は掲載不可となった理由 書を添えて投稿者に連絡しなければならない。

\section{第3条（投稿規定および執筆要領）}

投稿規定および執筆要領については別に定める。

付則：平成 3 年 4 月 1 日制定。

平成 6 年 4 月 6 日一部改定。

平成 8 年 4 月 4 日一部改定。

平成15年 9 月 16 日一部改定。

平成18年 2 月 2 日一部改定。

\section{森林計画学会誌投稿規定}

\author{
(平成17年 9 月 20 日一部改定)
}

1. 投稿者は森林計画学会の会員に限る。ただし，編 集委員会が原稿を依頼した場合この限りではない。 また，筆頭者以外の共同執筆者には非会員を含むこ とができる。

2. 原稿は, 和文で, 未発表のものに限る。ただし, 編集委員会がとくに必要と認めた場合は, この限り ではない。

3. 原稿の種類は, 論説, 論文, 短報, 資料, 提言, 解説, 学会記事, 会員の広場, 書評, そのほかとす る。総説は一定の研究分野について系統的に概観し, 課題の整理や評価・展望を抢こなっているもの。論 文は独創的な学術研究について理論的にまとめたも の。短報は独創的な学術研究の成果を短くまとめた 速報性を有するものであり，事例報告など公表の価 值があるものを含む。資料は独創的な学術研究の過 程で得られたデー夕，資料で公表の価值があるもの。 提言は森林に関わる意見を広く社会一般に対して述 べたものである。解説は研究成果などを分かりやす
く説明あるいは紹介したものである。学会記事は学 会が主催したシンポジウム等の記録。会員の広場は 会員間の親睦や情報交換などの場となる記事である。 書評は森林計画学およびその周辺科学に関する書籍 の書評。

4. 各種原稿の規定の長さは次のとおりである。総説 及び論文は刷り上がり 14 ページ以内。短報は刷り上 がりが8ページ以内。資料, 提言, 解説は論文に準 ずる。学会記事は短報に準ずる。会員の広場の原稿 は刷り上がりが 4 ページ以内。書評は刷り上がりが 2 ページ以内。なお, 編集委員会の判断で上記規定 の分量を超過した原稿の掲載を認める場合がある。

5. 総説, 論文, 短報については, 編集委員会が依頼 した 2 名以上の査読者による查読結果をもとに編集 委員会の議を経て掲載が決定される。これ以外の原 稿については編集委員会が独自に判断し, 原稿の採 否を決定する。

6. 原稿は執筆要領による。 